\title{
An Assessment of Governmental Services in the Philippines from Spanish to Contemporary Times ${ }^{1}$ \\ Lizan E. Perante-Calina, DPA ${ }^{\mathrm{a}}$ and Alex B. Brillantes, Jr., PhD $^{\mathrm{b}}$
}

\begin{abstract}
This paper delves on the governmental services in the Philippines highlighting the delivery of services to the transacting public characterized by bureaucratic inefficiency that engenders corruption. The assessment begins with a description of the state of governmental services from Spanish era to contemporary times. The review takes on public sector reforms by citing the efforts of the government to dispense with bureaucratic red tape, including pre-Anti Red Tape Act reform initiatives, the contextualization of the Citizen's Charter at the national and local level, and the ease of doing business as the new road map towards an efficient, effective, and economical public service delivery.
\end{abstract}

Keywords: Service Delivery Philippines; ARTA; Ease of Doing Business; Citizen's Charter

\section{Introduction}

This paper reviews the literature on the subject of the Citizen's Charter (CC), the prime component of the Anti-Red Tape Act (ARTA), but begins with the background of governmental services in the Philippines, highlighting the delivery of these services to the transacting public characterized by bureaucratic inefficiency that only engenders corruption. From there, the review takes on public sector reforms to curb inefficiency and corruption but equally important is the contextualization of the $\mathrm{CC}$ as the center of this paper.

It can be recalled that in 2007, the Philippine government introduced one of the conspicuous policy tool in improving its frontline service delivery, which is the Anti-Red Tape Act (ARTA) of 2007 (Republic Act No. 9485). The law provides an enabling framework for the adoption of the $\mathrm{CC}$ that originated in the United Kingdom and was later on introduced in the polity to streamline government processes and procedures. In the same manner, the ARTA as the legal framework to which the CC is anchored, aims to improve efficiency in the delivery of frontline services (FS) by reducing bureaucratic red tape and preventing graft and corruption.

\section{Review of related literature}

${ }^{1}$ This paper is an excerpt from the dissertation of Perante-Calina entitled "Improving Frontline Service Delivery and Accountability: The Implementation of The Citizen's Charter in the National Statistics Office and the National Bureau Of Investigation." 
The country's national hero, Dr. Jose Rizal, in his essay "La Indolencia de los Filipinos" (The Indolence of the Filipinos), which was published in 1888 in installments in the Propaganda Movement's bimonthly, La Solidaridad, first described how officers in government functioned. Rizal details the difficulties of Filipinos in trying to engage in business, for they know,

"how many documents,... how many stamped papers, how much patience is needed to secure from the government a permit for enterprise. One must count upon the good will of this one, on the influence of that one, on a good bribe to another in order that the application be not pigeonholed, a present to the one further on so that he may pass it on to his chief; one must pray to God to give him good humor and time to see and examine it; to another, talent to recognize its expediency; to one further sufficient stupidity not to scent behind the enterprise an insurrectionary purpose...And above all, great patience, great knowledge of how to get along, plenty of money, a great deal of politics, many salutations, great influence, plenty of presents and complete resignation!"(Fores-Ganzon, G., 1996, translation of Rizal's La Solidaridad, 1890).

The Americans who came in as the new colonial rulers confirmed the inefficiency and the rampant corruption in Spanish governance. Citing the report of the Philippine Commission, Jacobini and Associates (1956: 5) observed that governmental services in the Spanish period were "not well developed," that the Spanish government was "exploitative," "did not even achieve the basic objective of good government in that it was not able to maintain peace and order," did not sustain a "satisfactory level in the administration of justice," "no public works nor road maintenance, and no more than the rudiments of a system of public education."

Jacobini and Associates similarly describe governmental services in the new Philippine Republic after the Second World War. Governmental services have increased and expanded in coverage, but they point out that many of the services are poorly developed.

What these shortcomings are may include what they found: lack of fire fighting equipment in the municipalities, need for some artesian wells, more school buildings, more rural roads. In education, however, they point out that efforts are tremendous and the results gratifying. Nevertheless, Jacobini and Associates (1956: 11, 26, 30-31, 59) go on to say that public service suffers in many ways: the level of political morality leaves much to be desired, in that private pockets are lined up with public funds usable to advance services; the people are not assured of legal remedies for their grievances; and before a building is constructed in Manila, a permit must first be secured from the city engineer's office which sees to it that plans comply with the requirements of the building code, and that they are faithfully followed in the construction. Then there are accounts 
that the virtues of efficiency and politeness are not always manifest even in Philippine consulates and diplomatic establishments.

Many newspaper and magazine articles narrate the same sorry state of public services in the Philippines in contemporary times. W.S. Baun (Philippine Graphic, October 14, 1996) narrates the context of the sponsorship of House Bill 7058 (the future ARTA law) by the Chair of the House Committee on Civil Service and Professional Regulations, Representative Antonio V. Cuenco of Cebu. Cuenco identified the top ten most red tape-ridden agencies: 1) Department of Foreign Affairs, 2) Civil Service Commission, 3) Bureau of Customs, 4) Land Transportation Office, 5) Government Service Insurance System, 6) Social Security System, 7) Philippine Veterans Affairs Office, 8) National Census and Statistics office, 9) civil registries, and 10) registers of deeds. Concerning the DFA, Cuenco has this to say: It "is riddled with employees who do nothing but polish their fingernails, engage in telebabad, talk of Marimar, or ruminate lotto numbers. But if you give P100 as the regulation says, your passport will be approved in one day." The article concludes that red tape is a key factor in the citizenry's disaffection toward the government.

The above is a picture of the public services in the Philippine bureaucracy, characterized by red tape, inefficiency and corruption. It has a long history, inherited from Spanish times. The long reinforcement has only spawned attitudes and behavior that have continued up to the present.

It cannot be denied that the bureaucracy is sheathed by rules and regulations that resulted to bureaucratic red tape. The term "red tape," according to Kaufman (1977: 1) was derived "from a ribbon once used to tie up legal documents in England." These legal documents were part of the records of judicial courts wherein "common law gives great weight to precedent." From such origin, the phrase has evolved to become clearly a negative phenomenon of public bureaucracy. It has come to be associated with complaints from the people due to excessive bureaucratic regulations and procedures. A scholarly definition views "red tape as guidelines, procedures, forms and government interventions that are perceived as excessive, unwieldy, or pointless in relationship to decision making or implementation of decisions" (Rosenfeld 1984: 603, cited in Bozeman and Feeney).

Red tape has often been a staple excuse offered by government functionaries in rationalizing administrative inefficiency or inaction (Reyes, 1982:273), which is discussed in juxtaposed to corruption.

As pointed out by Professor Robert Klitgaard (1988), corruption may be represented as following a formula: $C=M+D-A$. Corruption equals monopoly plus discretion minus accountability (1998:4). This suggests that decreasing either or both "Monopoly and Power" and "Discretion" in government transactions, and/or increasing the "Accountability" of public officials, will correspondingly reduce "Corruption" (Ursal, 
2006: 2). In the international community, red tape has been associated with corruption and declining trust in government (Walker and Brewer 2008:1112).

\section{Discussion}

Reforms in the bureaucracy did not occur in the Philippines due to Western efforts done in improving the bureaucracy and its public services delivery. Indeed, in the past, it cannot be understated that the Philippine government had formulated remarkable bureaucratic reforms.

At the local level, there were several local government units (LGUs) that have introduced innovations in terms of frontline service delivery by crafting their own $\mathrm{CC}$ prior to the enactment of Republic Act 9485. One was Naga City's Citizen's Charter: A Manual of Government Services way back in 1997 through the support of the USAID (Saguin, 2012:3). Among the LGUs that have crafted the CC were Iligan (Giya sa SerbisyongLokal: A Guide on Iligan City Government Services); Sorsogon (Citizen's Charter of Sorsogon City: Guidebook on Key Government Services); Laoag (Laoag City Service: Charter Most Valued Factbook); Dumaguete (Dumaguete Citizen's Transactions Guidebook); Bacolod (Citizen's Charter of Bacolod City); and Digos (Digos City Services Handbook) under the assistance of the British Embassy. It is also noted that Marikina City was way ahead in formulating and implementing its Citizen's Charter Factbook (Saguin 2012:3), which was in 2004. However, the City Government of Naga has been implementing its CC since 2001 and published its guidebook on key government services under the USAID funded-project.

There are also a number of legal frameworks that safeguard the right of the public against unscrupulous government transactions but not specifically on anti-red tape which include Republic Act Number 6713 or the "Code of Conduct and Ethical Standards for Government Officials and Employees" articulating reforms on public administrative system, transparency of transactions and access to information and among other provisions; and Republic Act No. 3019 or the Anti Graft Law which covers provisions on what are prohibited transactions and what constitutes graft and corruption and the corresponding penalties attached thereto.

After the EDSA Revolution, the CSC through the efforts of then CSC Chairperson Patricia Sto. Tomas, launched in September 1988, the "Do Away with Red Tape" or DART. This public reform aimed to make the civil service responsive and fully aware of the importance of rendering honest and efficient service; and to curb and reduce red tape and corruption in all government operations (Doyo, 1989: 6).

The CSC has been implementing reform measures in eradicating bureaucratic red tape such as the MamayanMuna, Hindi Mamaya $\mathrm{Na}$ and the Public Service Delivery Audit (PASADA). Launched in 1994 as a client satisfaction program, the MamayanMuna, Hindi Mamaya $\mathrm{Na}$ was introduced "to promote public service improvement and eradicate discourtesy arrogance and inefficiency in the government" 
(CSC, Breakthrough... n.d.: 16). PASADA was initiated in 2003 and intended to complement Mamayan Muna, Hindi Mamaya Na.

Subsequent to the enactment of Republic Act No. 9485, a surfeit of policies and circulars has saturated the bureaucracy. One of these is the program known as CURE or the Comprehensive and Unified Response to Eliminate Red Tape in Local Government Programs, which aims to support the capacity development of local governments in order to institutionalize a sustainable and business friendly environment for an effective and efficient delivery of frontline services.

Recently, the integrated ARTA program was launched by the CSC by enhancing its "existing audit tool, reinforcing related technical assistance, increasing CSC's frontline monitoring presence and aspiring for an expanded coverage" (CSC, Breakthrough...n.d.: 17). The integrated ARTA program envisage to involve the citizens as end users of frontline serves in the "closed-loop linkage of the ARTA Watch, Contact ng Center ng Bayan, Report Card Survey" as described by the CSC (CSC, Breakthrough...n.d.: 17). These tools under the program including related activities are expected to enhance service delivery and discourage fixing, bribery and corruption.

Following the call for a graft-free country, several initiatives have been implemented both at the national and local levels including constitutional and statutory government agencies to comply with the Philippine Transparency Seal, ARTA, PhilGEPS, Performance Appraisal System and streamlined procedures and processes, which all part of the accountability mechanisms of the government.

For some four decades, most of the major public sector reform initiatives can be "attributed to various developments in the world: the citizen's quest for efficient and effective public service delivery, the economic and fiscal pressure on governments in the 70 's and early 80's and the revival of new right politics ('Reganomics' and 'Thatcherism')" (Nigussa 2013:1).

And the strong impetus for bureaucratic reform for efficient and effective delivery of public services came from the United Kingdom. The initiative came from Prime Minister Margaret Thatcher who introduced market principles into the public sector, in a process called privatization in the late $80 \mathrm{~s}$. The assumption was that the state was less effective in service delivery functions than the private sector. The rising confidence in the capacity of the market to lead the development process also led Osborne and Gaebler to advocate the reinventing government proposition in the early $90 \mathrm{~s}$.

Then came the $\mathrm{CC}$. The $\mathrm{CC}$ was introduced by the Prime Minister of the United Kingdom, John Major, who succeeded Thatcher. In the White Paper The Citizen's Charter: Raising the Standard, published in 1991, Major "envisioned an accountable, citizen-friendly and transparent administration that will improve performance management, prevent corruption, and engage citizens in public affairs" (Pollitt, 1994: 1).

The "charter" is "a document issued by a sovereign or state, outlining the conditions under which a corporation, colony, city, or other corporate body is organized, 
and defining its rights and privileges" (dictionary.reference.com/, retrieved on May 8, 2015). It is a "grant or guarantee by a government of rights, franchises, or privileges from the sovereign power of a state or country" (Merriam-webster.com/, retrieved on May 8, 2015).

In 1992, when the first report on Citizen's Charter was circulated, Major prescribed the six principles of public service, namely: 1) Setting, monitoring and publication of explicit standards; 2) Information for and openness to the service user; 3) Choice wherever practicable, plus regular and systematic consultation with users; 4) Courtesy and helpfulness; 5) Well-publicized and easy-to-use complaints and procedures; and 6) Value for money.

In the Philippine context, "the effectiveness of the Citizen's Charter to address red tape can be attributed to the principles underpinning it" (DAP 2010:26-29). These include “(1) Treating service users as clients; (2) Delivering quality public service; (3) Improving transparency in service delivery; (4) Treating all fairly; (5) Enhancing client involvement; (6) Putting things right when they go wrong; (7) Striving for continuous service improvement; (8) Providing value for money ; (9) Instilling mutual accountability; (10) Increasing predictability."

\section{Summary and conclusions}

The review of the governmental services took up what had already been published about the topic of red tape, ARTA and the CC. It began with a description of the state of governmental services in the Philippines, then went on to define "bureaucracy" and its dysfunctions such as red tape that leads to corruption. The literature traces the origins of red tape and corruption as well. Bureaucratic reforms follow, citing the efforts of the government to dispense with bureaucratic red tape, including pre-ARTA reform initiatives at the national and local level.

The literature points out the importance of citizens participating in the ARTA and CC implementation, and the need to install ICT systems to improve CC implementation and improve FSD. The good governance principle on accountability and its indicators, are likewise discussed in association to the principles of transparency, rule of law, and due process which are vital in all strata of development.

The imperative of studying the $\mathrm{CC}$ is central to public sector reform and governance particularly in ensuring efficient and effective delivery of public services as the $\mathrm{CC}$ is considered a new approach to public sector reform particularly in the delivery of frontline services. In the Philippine context, the Citizen's Charter may be traced to the demands of the citizens to make government processes simple and fast but have quality in the rendition of frontline services. Such demands prompted the Philippine Congress to make an initiative to prioritize public interest amidst bureaucratic inefficiencies that only lead to red tape, corruption and unprofessionalism. 
However, the review implies that there is dearth of studies on the empirical contribution of the $\mathrm{CC}$ on public sector reform as well a on the active participation of citizens in the crafting, implementation, and monitoring of the $\mathrm{CC}$. Hence, this paper explores to contribute significant results on the implementation of the CC particularly in the Philippines and fill in the gaps that exist in the body of knowledge.

At present, the Philippine government is proposing to amend the ARTA which the $\mathrm{CC}$ is anchored by establishing a national policy on ease of doing business and creating for a commission which will someone add another layer in the politico-administrative system.

\section{References}

Alfiler, Ma. Corazon, P. (1995). The Political-Administrative Accountability Continuum in Philippine Public Service, Conquering Politico-Administrative Frontiers, Essays in Honor of Raul P. de Guzman, L. V. Carino (Eds)., Quezon City: College of Public Administration and the University of the Philippine Press.

Asian Development Bank (ADB) (1999). Governance Sound Development Management, Our Framework Policies and Strategies. Manila. Philippines. Retrieved from: http://adb.org/sites/default/files/pub/1995/govpolicy.pdf.

Asian Development Bank (ADB) (2005). Country Governance Assessment. Mandaluyong, Philippines.

Asian Development Bank (ADB) (2003). Toward e-Development in Asia and the Pacific: A Strategic Approach for Information and Communication Technology, Policies and Strategies. Retrieved from: http://unpan1.un.org/intradoc/groups/public/documents/undpadm/unpan043094.pdf.

Argyris, Chris (1960). On Organizational Learning, London: Tavistock

Baun, Willie S. (1996). Criminalizing Red Tape." Philippine Graphic, 7 (19) (October 14, 1996), pp. 17, 45.

Carlos, Clarita R. (2006). "Towards A New Model of Bureaucracy in the Philippines" in The Local Government Bureaucracy and Local Fiscal Administration, Local Government Development Foundation (Eds. Preschle and Sosmena, Jr), Konrad Adenauer Stiftung, Philippines pp 12-31.

Clegg, Stewart (2007). "Bureaucracy and Public Sector Governmentality." In The Blackwell Encyclopedia of Sociology, Vol. I (pp. 376-378). Malden, MA: Blackwell Publishing.

Dacanay, Alex (1989). Protecting People from Red Tape and Bureaucracy. Philippine Panorama, 18 (10) (March 5, 1989), pp. 14-17.

Doyo, Ma. Ceres P. (1989). Dart away with red tape. Sun Inquirer Magazine 3 (55) (January 15, 1989), pp. 6-7. 
Fores-Ganzon, G., trans. (1996). La Solidaridad. Vols. 1 \& 2. Pasig: Fundacion Santiago.

Guillermo, Mariano J. (2006). "Operative Norms and Values in the Local Bureaucracy" in The Local Government Bureaucracy and Local Fiscal Administration." Local Government Development Foundation (Ed. Preschle and Sosmena, Jr), Konrad Adenauer Stiftung, Philippines pp 21-31.

Hale S. and A.C. Hyde (1994). Reengineering in the Public Sector. Public Productivity and Management Review, Volume 18, No. 2, Winter. Jossey-Bass Publishers.

Hammer, Michael and Champy, James (1993). Reengineering the Corporation, A Manifesto for Business Revolution. Harper Business, Harper Collins Publishers, New York.

Hartley, Jean (2004). Innovation in Governance and Public Service, Innovations in Governance. Module on Executive Program. Harvard University, John F. Kennedy School of Government Executive Program, December 5-10, 2004.

Hedley, Timothey P. (1998). Measuring Public Sector Effectiveness Using Private Sector Methods. Public Productivity and Management Review, Vol. 21, No.3, March 1998 pp 251-258.

Jacobini, H.B. and Associates (1956). Governmental Services in the Philippines. Institute of Public Administration, University of the Philippines, Manila.

Kaufman, Herbert. (1977). Red Tape, Its Origins, Uses and Abuses. Washington, D.C. The Brookings Institution.

Klitgaard, Robert (1988). Controlling Corruption. University of California Press, Berkeley and Los Angeles.

Klitgaard, Robert. (1997). Cleaning Up and Invigorating the Civil Service. Public Administration and Development, Volume 17, pp 487-509.

Lane, Jan-Erik (1987). Introduction: The Concept of Bureaucracy in Bureaucracy and Public Choice. Jan-Erik Lane (Ed.) (pp. 1-30). London: SAGE Publications.

Lane, Jan Erik (1997). Introduction: Public Sector Reform: Only Deregulation, Privatization and Marketization? in Public Sector Reform, Rationale, Trends and Problems, Jan-Erik Lane (Ed).) (pp 1-16). London.

Likert, Rensis (1961). New Patterns of Management. New York: McGraw-Hill.

Merton, Robert, K. (2007). Bureaucratic Structure and Personality, Classics of Public Administration, (Eds) Jay M. Shafritz and Albert C. Hyde, Sixth Edition, Thomson Wadsworth, U.S.A.

Mullen, J., (n.d.). John Major's Citizen's Charter, Fifteen Years Later. Retrieved from books.google.com/ph/

Nigussa, Fekadu (2013).Cross Country Experiences of Citizens' Charter Implementation. Cross Country Experience of Citizen's Charter Implementation. Retrieved from: http://theglobaljournal.net/article/view1140/ 
Perante-Calina, Lizan (2015). Improving Frontline Service Delivery and Accountability: The Implementation of The Citizen's Charter in the National Statistics Office and the National Bureau Of Investigation. University of the Philippines, National College of Public Administration and Governance, Diliman, Quezon City, Philippines.

Pollitt, Christopher (1994). The Citizen's Charter: A Preliminary Analysis in Public Money and Management. Volume 14, Issue 2, pp 9-14, Blackwell Publishers, Cambridge, MA, United States of America. Retrieved from www.tandfonline.com/.

Pollitt, Christopher (1993). Managerialism and the Public Services. $2^{\text {nd }}$ Edition. London, Blackwell.

Rosenfeld, R.A. (1984). An Expansion and Application of Kaufman's Model of Red Tape: The Case of Community Development Block Grants. Western Political Quarterly, pp. 37 603-620.

Saguin, Kidjie Ian C. (2012). Critical Challenges in Implementing the Citizen's Charter Initiative: Insights from Selected $L G U s$, Policy Research Office, Center for Governance, Development Academy of the Philippines.

Seely, Anthony and Peter Jenkins (1995). The Citizen's Charter Research Paper 95/66. House of Commons. Retrieved from researchbriefs.files.parliament.uk/Cm 1599 July 1991.

Sosmena, Gaudioso C., Jr. (2006). Local Government Bureaucracy in The Local Government Bureaucracy and Local Fiscal Administration, Local Government Development Foundation (ed. Preschle and Sosmena, Jr), Konrad Adenauer Stiftung, Philippines pp 1-11.

United Nations (2013). Citizen Engagement and the Post 2015 Development Agenda, Report of the Expert Group Meeting, Department of Economic and Social Affairs, Development of Public Administration and Development Management, E/ESCWA/ECNI 2013/WG. 1 Report.

United Nations (2005). Human Resources for Effective Public Administration in a Globalized World,Department of Economic and Social Affairs, Division for Public Administration and Development Management.

VanBruaene, Michael (2011). Useful Performance Measures \& Metrics - How To Measure Efficiency \& Effectiveness in Pragmatic Approaches to Move You and Your Organization Forward. Retrieved from:

http://www.advancingyourorganization.com/?p=1071

Villarama, Martin J, Jr. (2007), Culture of Delay, The Court of Appeals Journal, Philippines.

Whyte, William H., Jr. (1956). The Organization Man. New York: Simon and Schuster. 
World Bank (2003). (Grace, et. al), Information and Communication Technologies and Broad-Based Development, A Partial Review of the Evidence, Working Paper No. 12.

World Bank (n.d). Dealing with Governance and Corruption Risks in Project Lending, How-To Notes Citizen Charters: Enhancing Service Delivery through Accountability, Social Development, GAC Projects, Improving Development Outcomes, $\quad$ Retrieved from: http://dfgg; $\underline{\text { http://gacinprojects, }}$ http://sitesources.worldbank.org

Yangco, Mario (1988), Civil Service Commissioner, DART's Success - The Success of Everyone. Civil Service Reporter, July-December 1988.

\section{Laws, government issuances}

Republic Act Number 9485 (2007). An Act to Improve Efficiency in the Delivery of Government Service to the Public by Reducing Bureaucratic Red Tape, Preventing Graft and Corruption, and Providing Penalties Therefor, Philippine Congress.

Republic Act Number 6713 (1989). Code of Conduct and Ethical Standards for Public Officials and Employees.

\section{Internet sources}

www.adb.org

http://darpg.nic.in/darpgwebsite_cms/Document/file/IIPA_Report_Citizen_Charter.pdf http://web.csc.gov.ph/cscsote2/2014-02-21-08-23/pdf

www.dictionary.reference.com

www.meriam-webster.com

www.unpan1.un.org 